\title{
EFEKTIVITAS METODE GABUNGAN MEDIA FILTER CANGKANG KERANG (Anadara granosa) DAN KARBON AKTIF UNTUK MENURUNKAN Fe DAN ZAT ORGANIK AIR BERSIH
}

\author{
Dian Indah Pratiwi ${ }^{1}$ dan Rasman² \\ Jurusan Kesehatan Lingkungan Politeknik Kesehatan Kemenkes Makassar \\ (dianindahpratiwi.DP@gmail.com)
}

\begin{abstract}
Source of water is one of the main components in the water supply system because, without a water source, the clean water supply system will not function. Water with poor quality is caused by iron pollution and organic matter. One simple method that can be used is water treatment, namely filtration (filtering) using a blood clamshell filter media (Anadara granosa), activated carbon, and a combination of activated carbon shells. This study aims to determine the effectiveness of shellfish (Anadara granosa) and activated carbon filter media methods to reduce clean water Fe and organic matter. This type of research is a quasi-experimental design with a pretest-posttest with a control group design and carried out with three replications. Data from laboratory research and examination results were then processed and analyzed using One-way ANOVA statistical tests. The results for $\mathrm{Fe}$ and organic matter in the dug well water before processing was $3.23 \mathrm{mg} / \mathrm{l}$ and $51.38 \mathrm{mg} / \mathrm{l}$ and after processing with clamshell media it was $0.22 \mathrm{mg} / \mathrm{l}$ and $634.94 \mathrm{mg} / \mathrm{l}$, with Activated carbon media is $0.14 \mathrm{mg} / \mathrm{l}$ and $36.33 \mathrm{mg} / \mathrm{l}$, with the media combination the activated carbon shells are $0.23 \mathrm{mg} / \mathrm{I}$ and $23.32 \mathrm{mg} / \mathrm{l}$. The decrease in Fe with clamshell media activated carbon, and combination effective while in decreasing organic matter is not effective. For the community, this water treatment can be applied on a household scale and other researchers can make other variations such as the thickness of the media used.
\end{abstract}

Keywords: Filtration, Seashell, Activated Carbon, Iron, and Organic Substances

\section{ABSTRAK}

Sumber air merupakan salah satu komponen utama yang ada pada suatu sistem peyediaan air bersih, karena tanpa sumber air maka suatu sistem penyediaan air bersih tidak akan berfungsi. Air dengan kualitas buruk salah satunya disebabkan oleh pencemaran besi dan zat organik. Salah satu cara yang sederhana yang dapat digunakan adalah dengan pengolahan air yaitu dengan cara filtrasi (penyaringan) dengan menggunakan media penyaring cangkang kerang darah (Anadara granosa), karbon aktif dan kombinasi media cangkang kerang-karbon aktif.Penelitian ini bertujuan untuk mengetahui efektivitas metode media filter cangkang kerang (Anadara granosa) dan karbon aktif untuk menurunkan Fe dan Zat organik air bersih. Jenis penelitian ini yaitu experiment semu dengan rancangan pretes-posttest with control group design, dan dilakukan dengan tiga kali replikasi. Data hasil penelitian dan pemeriksaan Laboratorium kemudian diolah dan dianalisis menggunakan uji statistic One way anova. Hasil untuk kadar Fe dan zat organik pada air sumur gali sebelum pengolahan adalah 3,23 mg/l dan 51,38 mg/l dan setelah pengolahan dengan media cangkang kerang adalah 0,22 $\mathrm{mg} / \mathrm{l}$ dan $634,94 \mathrm{mg} / \mathrm{l}$, dengan media karbon aktif adalah $0,14 \mathrm{mg} / \mathrm{l}$ dan $36,33 \mathrm{mg} / \mathrm{l}$ dengan, dengan kombinasi media cangkang kerang-karbon aktif adalah $0,23 \mathrm{mg} / \mathrm{l}$ dan $23,32 \mathrm{mg} / \mathrm{l}$. Penurunan Fe dengan media cangkang kerang,karbon aktif dan kombinasi efektif sedangkan dalam penurunan zat organik tidak efektif. Bagi masyarakat, pengolahan air ini dapat diterapkan dalam skala rumah tangga dan bagi peneliti lain dapat membuat variasi lain seperti ketebalan media yang digunakan.

Kata Kunci : Filtrasi, Cangkang Kerang, Kabon Aktif, Besi dan Zat Organik

\section{PENDAHULUAN}

Untuk memenuhi kebutuhan air bersih manusia biasanya memanfaatkan air yang ada disekitar tempat tinggal, baik dari air alam maupun setelah mengalami proses pengolahan terlebih dahulu. Masalah utama yang dihadapi oleh sumber meliputi kuantitas air yang sudah tidak mampu memenuhi kebutuhan yang terus meningkat dan kualitas air untuk keperluan domestik yang semakin menurun.

Air di alam mengandung berbagai zat terlarut dan tidak larut. Air di alam juga mengandung berbagai mikroorganisme. Apabila kandungan yang terdapat dalam air tidak menganggu kesehatan manusia, maka air tersebut dapat dianggap bersih (Aliya. 2006).

Sumber air merupakan salah satu komponen utama yang ada pada suatu sistem peyediaan air bersih, karena tanpa sumber air maka suatu sistem penyediaan air bersih tidak akan berfungsi (Sutrisno, 2000).macam sumber air yang dapat dimanfaatkan sebagai air minum yaitu : air angkasa (air hujan), air permukaan, dan air tanah.
Air tanah merupakan yang berada dibawah permukaan tanah. Yang berada pada akifer. Karakteristik utama yang membedakan air tanah dan air permukaan adalah pergerakan yang sangat lambat dan waktu tinggal (residence time) yang sangat lama, dapat mencapai puluhan bahkan ratusan tahun. Karena pergerakkan yang sangat lambat dan waktu tinggal yang lama tersebut, air tanah akan sulit untuk pulih kembali jika mengalami pencemaran. (Effendi. 2003).

Zat besi dibutuhkan oleh tubuh dalam jumlah yang kecil untuk pembentukkan sel-sel darah merah. Kandungan zat besi didalam air yang melebihi batas akan menimbulkan gangguan. Menurut Asmadi et al. (2011) air yang mengandung banyak besi akan berwarna kuning dan menyebabkan rasa logam besi dalam air, serta menimbulkan korosif pada bahan yang terbuat dari metal. Kadar besi (Fe) yang tinggi yang melebihi batas maksimal dikhawatirkan yangmenyebabkan akumulasi $\mathrm{Fe}$ dalam tubuh yang dapat mengakibatkan efek racun dalam tubuh manusia atau dapat mengakibatkan diare, 
anemia, iritasi pada mata, kulit dan kerusakan ginjal. (Rahmawanti. 2016).

Zat organik dalam air disebabkan karena air buangan dari rumah tangga, industri, kegiatan pertanian dan pertambangan. Zat organik dalam air dapat ditentukan dengan mengukur angka permanganatnya $\left(\mathrm{KMnO}_{4}\right)$. Kualitas air tersebut akan mengakibatkan timbulnya bau tidak sedap dan menimbulkan sakit perut.

Untuk menyikapi tingginya kadar Fe dan zat organik pada air sumur gali, salah satu cara yang sederhana yaitu filtrasi untuk mengolah air sumur bersih yang mengandung $\mathrm{Fe}$ dan zat organik yang melebihi batas maksimum.

Filtrasi adalah proses penyaringan partikel secara fisik, kimia dan biologi untuk memisahkan atau menyaring partikel yang tidak terendapkan di sedimentasi melalui media berpori. Selama proses filtrasi, zat-zat pengotor dalam media penyaring akan menyebabkan terjadinya penyumbatan pada pori-pori media sehingga kehilangan tekanan akan meningkat. (Joko. 2010).

Cangkang Kerang (Anadara granosa) merupakan hewan moluska (binatang lunak) yang memiliki dua buah cangkang. Anadara granosa mengandung kadar kalsium karbonat $\left(\mathrm{CaCO}_{3}\right)$ yang dapat menyerap senyawa anorganik dan organik. Kadar lebih tinggi bila dibanding batu gamping, cangkang telur, dan keramik (Dance. 1977, dalam Putra et al. 2013) sehingga dapat digunakan sebagai pemisah antara air dengan ion logam. Menurut Niswati et al. (2010), dalam Luthfiah (2015) semakin keras cangkang, maka semakin tinggi kandungan kalsium karbonat $\left(\mathrm{CaCO}_{3}\right)$ nya.

Karbon aktif adalah sejenis adsorbent (penyerap) berwarna hitam, berbentuk granular bulat, pelet, ataupun bubuk. Karbon aktif karena memilki sejumlah sifat kimia maupun fisika yang mampu menyerap zat organik maupun anorganik, dapat berlaku sebagai penukar kation dan sebagai katalis untuk berbagai reaksi. Jenis karbon aktif tempurung kelapa ini sering digunakan dalam proses penyerap rasa dan bau pada air, dan juga penghilang senyawa-senyawa organik dalam air.

\section{METODE}

\section{Desain, tempat, dan waktu}

Rancangan penelitian yang digunakan adalah pretest-posttest with control group design yaitu unit percobaan dikenakan perlakuan dengan dua kali pengukuran. Pengukuran pertama dilakukan sebelum proses pengolahan filtrasi dilaksanakan dan pengukuran kedua dilakukan sesudah proses pengolahan filtrasi dilaksanakan.
Penelitian ini menggunakan instrumen dengan rincian berupa reservoir/tendon dengan volume 100 liter, alat penyaringan yang dirancang menggunakan prinsip bejana berhubungan dengan pipa sebesar 4 inch dan volume 8 liter, pipa distribusi berdiameter $1 / 2$ inch dan dilengkapi dengan stop kran. Pengaliran air untuk inlet dengan aliran secara gravitasi sedangkan untuk outlet (sampel) dengan sistem arah aliran up flow. Media filter yang digunakan yaitu cangkang kerang dan karbon aktif dengan ketebalan media $60 \mathrm{~cm}$. . Variabel penelitian ini yaitu variabel bebas dan terikat yaitu proses filtrasi dengan media cangkang kerang darah (Anadara granosa) dan karbon aktif pada variasi media filter dan kombinasi susunan media. Sedangkan variabel bebas yaitu penurunan kadar besi $(\mathrm{Fe})$ dan zat organik $\left(\mathrm{KMnO}_{4}\right)$ pada air bersih.

Lokasi penelitian untuk pengambilan sampel yaitu air sumur gali di Kampung Sapiria, Kelurahan Lembo, Kecamatan Tallo, Kota Makassar dan pelaksanaan kegiatan eksperimen dilakukan di Workshop Jurusan Kesehatan Lingkungan Poltekkes Makassar. Lokasi untuk melakukan pemeriksaan sampel di Laboratorium Jurusan Kesehatan Lingkungan Poltekkes Makassar, Jl. Wijaya Kusuma 1/2 Kelurahan Banta-bantaeng, Kecamatan Rappocini, Kota Makassar.

\section{Populasi dan Sampel}

Populasi dan penelitian ini adalah air sumur gali yang berada di Kampung Sapiria, Kelurahan Lembo, Kecamatan Tallo, Kota Makassar. Air sumur gali yang akan digunakan sebagai sampel sebanyak 10 liter untuk satu kali perlakuan dan satu kontrol, jadi jumlah sampel untuk tiga perlakuan dan satu kontrol membutuhkan air sebanyak 40 liter. Sehingga jumlah total sampel air yang digunakan dengan pengulangan sebanyak tiga kali yaitu 120 liter.

\section{Pengumpulan Data}

Data primer diperoleh dari hasil pemeriksaan sampel air baik sampel pretest sebelum perlakuan maupun sampel posttest setelah perlakuan di Laboratorium Kimia Jurusan Kesehatan Lingkungan Poltekkes Makassar. Data sekunder diperoleh dari penelusuran perpustakaan berupa buku-buku, jurnal, karya ilmiah berupa skripsi, tesis, dan disertasi,

\section{Pengolahan dan Analisis Data}

Data yang diperoleh berdasarkan hasil pemeriksaan laboratorium kemudian diolah dengan menggunakan komputer/kalkulator. Data dianalisis menggunakan uji statistik anova satu arah dengan menggunakan program komputer 
Jurnal Sulolipu : Media Komunikasi Sivitas Akademika dan Masyarakat

Vol. 20 No. 12020

e-issn : 2622-6960, p-issn : 0854-624X

SPSS dan data yang telah dianalisis disajikan dalam bentuk tabel.

\section{HASIL}

Tabel 1

Rata-rata Kadar Besi (Fe) Setelah Melalui Filtrasi Media Cangkang Kerang pada Air Sumur Gali Di Kampung Sapiria Tahun 2019

\begin{tabular}{|c|c|c|c|c|}
\hline \multirow{3}{*}{$\begin{array}{c}\text { Sebelum } \\
\text { Perlakua } \\
n\end{array}$} & \multirow{3}{*}{$\begin{array}{c}\text { Pengulanga } \\
n\end{array}$} & \multicolumn{2}{|c|}{ Kadar Fe (mg/l) } & \multirow{2}{*}{$\begin{array}{c}\text { Efektivitas } \\
\text { Penuruna } \\
\text { n (\%) }\end{array}$} \\
\hline & & \multicolumn{2}{|c|}{$\begin{array}{c}\text { Setelah } \\
\text { Perlakuan }\end{array}$} & \\
\hline & & $\begin{array}{c}\text { Kontr } \\
\text { ol }\end{array}$ & $\begin{array}{c}\text { Cangk } \\
\text { ang } \\
\text { Kerang }\end{array}$ & $\begin{array}{c}\text { Cangkang } \\
\text { Kerang }\end{array}$ \\
\hline \multirow{3}{*}{3,23} & 1 & 2,41 & 0,15 & 95,35 \\
\hline & 2 & 2,44 & 0,32 & 90,09 \\
\hline & 3 & 2,92 & 0,19 & 94,12 \\
\hline \multicolumn{2}{|c|}{ Rata-rata } & 2,59 & 0,22 & 93,19 \\
\hline
\end{tabular}

Tabel 2

Rata-rata Kadar Zat Organik $\left(\mathrm{KMnO}_{4}\right)$ pada Air Sumur Gali Di Setelah Melalui Filtrasi Media Cangkang Kerang pada Air Sumur Gali Di Kampung Sapiria Tahun 2019

\begin{tabular}{|c|c|c|c|c|}
\hline \multirow{3}{*}{$\begin{array}{c}\text { Sebelum } \\
\text { Perlakua } \\
\mathrm{n}\end{array}$} & \multirow{3}{*}{$\begin{array}{l}\text { Pengu } \\
\text { langan }\end{array}$} & \multicolumn{2}{|c|}{ Kadar Mn (mg/l) } & \multirow{3}{*}{$\begin{array}{c}\text { Efektivita } \\
\text { s } \\
\text { Penuruna } \\
\mathrm{n}(\%) \\
\begin{array}{c}\text { Cangkan } \\
\text { g Kerang }\end{array}\end{array}$} \\
\hline & & \multicolumn{2}{|c|}{ Setelah Perlakuan } & \\
\hline & & Kontrol & $\begin{array}{l}\text { Cangkan } \\
\text { g Kerang }\end{array}$ & \\
\hline \multirow{3}{*}{51,38} & 1 & 20,41 & 637,94 & -1141 \\
\hline & 2 & 26,60 & 630,94 & -1127 \\
\hline & 3 & 43,35 & 635,94 & -1137 \\
\hline \multicolumn{2}{|c|}{ Rata-rata } & 30,12 & 634,94 & -1225 \\
\hline
\end{tabular}

Sumber : Data Primer

Tabel 3

Rata-rata Kadar Besi (Fe) Setelah Melalui Filtrasi Media Karbon Aktif pada Air Sumur Gali Di Kampung Sapiria Tahun 2019

\begin{tabular}{|c|c|c|c|c|}
\hline \multirow{3}{*}{$\begin{array}{c}\text { Sebelum } \\
\text { Perlakua } \\
n\end{array}$} & \multirow{3}{*}{$\underset{n}{\text { Pengulanga }}$} & \multicolumn{2}{|c|}{ Kadar Fe (mg/l) } & \multirow{2}{*}{$\begin{array}{c}\text { Efektivitas } \\
\text { Penuruna } \\
\text { n (\%) }\end{array}$} \\
\hline & & \multicolumn{2}{|c|}{$\begin{array}{l}\text { Setelah } \\
\text { Perlakuan }\end{array}$} & \\
\hline & & $\begin{array}{c}\text { Kontro } \\
\text { I }\end{array}$ & $\begin{array}{l}\text { Karbo } \\
\text { n Aktif }\end{array}$ & $\begin{array}{l}\text { Karbon } \\
\text { Aktif }\end{array}$ \\
\hline \multirow{3}{*}{3,23} & 1 & 2,41 & 0,14 & 95,66 \\
\hline & 2 & 2,44 & 0,14 & 95,66 \\
\hline & 3 & 2,92 & 0,14 & 95,66 \\
\hline \multicolumn{2}{|c|}{ Rata-rata } & 2,59 & 0,14 & 95,66 \\
\hline
\end{tabular}
Filtrasi Media Cangkang Kerang-Karbon Aktif pada Air Sumur Gali Di Kampung Sapiria Tahun 2019

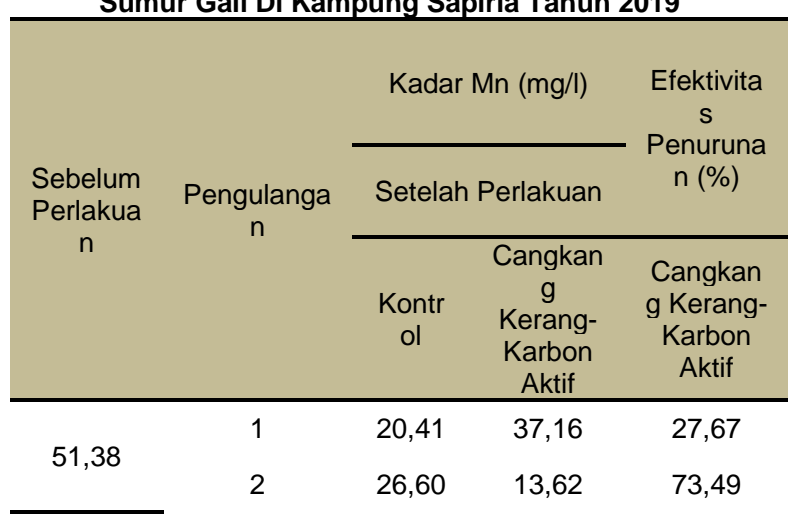

Rata-rata Kadar Besi (Fe) Setelah Melalui Filtrasi Media

Cangkang Kerang-Karbon Aktif pada Air Sumur Gali Di Kampung Sapiria Tahun 2019

\begin{tabular}{|c|c|c|c|c|}
\hline \multirow{3}{*}{$\begin{array}{l}\text { Sebelum } \\
\text { Perlakuan }\end{array}$} & \multirow{3}{*}{$\begin{array}{l}\text { Pengul } \\
\text { angan }\end{array}$} & \multicolumn{2}{|c|}{ Kadar Fe (mg/l) } & \multirow{2}{*}{$\begin{array}{c}\text { Efektivitas } \\
\text { Penurunan } \\
(\%)\end{array}$} \\
\hline & & \multicolumn{2}{|c|}{ Setelah Perlakuan } & \\
\hline & & Kontrol & $\begin{array}{l}\text { Cangkan } \\
\text { g Kerang- } \\
\text { Karbon } \\
\text { Aktif }\end{array}$ & $\begin{array}{l}\text { Cangkang } \\
\text { Kerang-Aktif }\end{array}$ \\
\hline \multirow{3}{*}{3,23} & 1 & 2,41 & 0,29 & 91,02 \\
\hline & 2 & 2,44 & 0,21 & 93,49 \\
\hline & 3 & 2,92 & 0,20 & 93,80 \\
\hline \multicolumn{2}{|c|}{ Rata-rata } & 2,59 & 0,23 & 92,77 \\
\hline
\end{tabular}

Sumber : Data Primer

Tabel 6

Rata-rata Kadar Zat Organik $\left(\mathrm{KMnO}_{4}\right)$ Setelah Melalui ur Gali Di Kampung

\begin{tabular}{|c|c|c|c|c|}
\hline \multirow{3}{*}{$\begin{array}{c}\text { Sebelum } \\
\text { Perlakua } \\
\mathrm{n}\end{array}$} & \multirow{3}{*}{$\begin{array}{c}\text { Pengulanga } \\
n\end{array}$} & \multicolumn{2}{|c|}{ Kadar Mn (mg/l) } & \multirow{2}{*}{$\begin{array}{c}\text { Efektivitas } \\
\text { Penuruna } \\
\mathrm{n}(\%)\end{array}$} \\
\hline & & \multicolumn{2}{|c|}{$\begin{array}{l}\text { Setelah } \\
\text { Perlakuan }\end{array}$} & \\
\hline & & $\begin{array}{c}\text { Kontro } \\
1\end{array}$ & $\begin{array}{l}\text { Karbo } \\
\text { n Aktif }\end{array}$ & $\begin{array}{l}\text { Karbon } \\
\text { Aktif }\end{array}$ \\
\hline \multirow{3}{*}{51,38} & 1 & 20,41 & 35,30 & 31,29 \\
\hline & 2 & 26,60 & 40,87 & 20,45 \\
\hline & 3 & 43,35 & 32,82 & 36,12 \\
\hline \multicolumn{2}{|c|}{ Rata-rata } & 30,12 & 36,33 & 29,28 \\
\hline
\end{tabular}

Sumber : Data Primer

Tabel 5 


\begin{tabular}{cccc}
3 & 43,35 & 19,20 & 62,63 \\
\hline Rata-rata & 30,12 & 23,32 & 54,59 \\
\hline Sumber : Data Primer & &
\end{tabular}

\section{PEMBAHASAN}

Air yang berada di bawah permukaan tanah. Pada dasarnya, air tanah dapat berasal dari air hujan (presipitasi), baik melalui proses infiltrasi secara langsung ataupun secara tak langsung dari air sungai, danau, rawa, dan genangan air lainnya (Effendi, 2003). Oleh karena air sumur gali yang terdapat di kampung Sapiria dari segi kualitas fisik dapat langsung terlihat tidak memenuhi syarat baik dari segi warna, kekeruhan, hingga bau pada air.

Mengingat kondisi geografi di kampung Sapiria dan kondisi lingkungannya padat penduduk dan adanya rawa mempengaruhi kualitas air bersih yang digunakan sebagai pengganti air PDAM jika tidak mengalir lancar pada wilayah tersebut.

Besi ( $\mathrm{Fe})$ terdapat dimana-mana baik dalam air maupun dalam tanah dalam berbagai bentuk. Merupakan ion logam yang sifat kimianya terlarut di dalam air, umumnya berada dalam keadaan bervalensi dua (divalent) atau ion ferous, Fe masuk ke dalam air oleh karena reaksi biologis pada kondisi reduksi atau anaerobik (tanpa oksigen) (Asmadi et al, 2011).

Air yang mengandung kadar besi tinggi dapat menimbulkan dampak. Fe yang melebihi dosis yang diperlukan oleh tubuh menimbulkan masalah kesehatan seperti terjadinya iritasi pada mata dan kulit bila kadar $\mathrm{Fe}$ lebih dari $1 \mathrm{mg} / \mathrm{l}$ (Rahmawanti, 2016).

Zat organik yang pada umunya merupakan bagian dari binatang atau tumbuhtumbuhan dengan komponen utamanya adalah karbon, protein dan lemak lipid. Oleh karena itu, penentuan zat organik dalam air menjadi salah satu parameter penting dalam penentuan kualitas air, karena bisa menjadi salah satu ukuran seberapa jauh tingkat pencemaran pada suatu perairan (Febrian. 2008). Menurut Asmadi (2011) Makin tinggi kandungan zat organik didalam air maka semakin jelas bahwa air tersebut telah tercemar, hewan atau oleh sumber lain. Menurut Krisma (2008) Keberadaan zat organik didalam air menimbulkan warna, rasa, kekeruhan yang tidak diinginkan, bau serta dapat membantu pertumbuhan bakteri.

\section{1) Untuk Menurunkan Fe dan Zat Air Bersih}

Besi (Fe) air sumur gali di Kelurahan Lembo, Kota Makassar menunjukkan cukup tinggi sebelum filtrasi yaitu $3,23 \mathrm{mg} / \mathrm{l}$, ini menunjukkan di atas ambang batas yang diperbolehkan yaitu $1,0 \mathrm{mg} / \mathrm{l}$. penelitian ini juga terdapat kontrol yaitu tidak ada perlakuan. Pada hasil kontrol didapatkan rata-rata $2,59 \mathrm{mg} / \mathrm{l}$ sedangkan filtrasi melalui media cangkang kerang didapati penurunan rata-rata hingga kadar $\mathrm{Fe}$ 0,22 mg/l dengan efektivitas 93,19\%. Putra et al. (2013) bahwa cangkang kerang yang digunakan sebagai media pengolahan air dapat mereduksi kadar besi $(\mathrm{Fe})$ sebesar 93.94\% pada air tanah.

Hasil Pemeriksaan kadar zat organik $\left(\mathrm{KMnO}_{4}\right)$ pada air sumur gali menunjukkan hasil yang cukup tinggi sebelum dilakukan perlakuan filtrasi yaitu $51,38 \mathrm{mg} / \mathrm{l}$ ini menunjukkan bahwa zat organik $\left(\mathrm{KMnO}_{4}\right)$ yang diperbolehkan yaitu $10 \mathrm{mg} / \mathrm{l}$. Selain perlakuan atau intervensi dalam penelitian ini juga terdapat control, yaitu tidak ada perlakuan atau tidak ada media filter yang diberikan. Pada hasil kontrol yang didapatkan rata-rata $30,12 \mathrm{mg} / \mathrm{l}$, sedangkan filtrasi media cangkang kerang didapatkan rata-rata zat organik $\left(\mathrm{KMnO}_{4}\right) 634,94 \mathrm{mg} / \mathrm{l}$, penggunaan media cangkang kerang sebagai media filter dikatakan tidak efektif karena tidak ada penurunan zat organik dari sampel awal setelah melalui media filtrasi.

Cangkang kerang darah memiliki kandungan $\mathrm{CaCO}_{3} \quad 98,7 \%$. Banyaknya kandungan mineral kalsium sebagai pembentuk tulang dan mineral $(\mathrm{Cu}, \mathrm{Fe}, \mathrm{Zn}$, dan $\mathrm{Si}$ ) yang berfungsi sebagai antioksidan serta proksimat dari kerang darah (Anadara granosa) (Ali. 2014, dalam Purba. 2018).

Menurut Slamet (2004), dalam Pradana (2018) cangkang kerang dapat digunakan sebagai limbah padat yang digunakan kembali lebih bernilai ekonomis terlebih digunakan sebagai media filter pengolahan air bersih yang dapat digunakan oleh masyarakat.

Kulit kerang merupakan bahan sumber mineral yang pada umumnya berasal dari hewan laut berupa kerang yang telah mengalami penggilingan dan mempunyai karbonat tinggi. Dapat dikatakan bahwa cangkang kerang tidak dapat digunakan untuk menurunkan zat organik karena cangkang kerang sendiri merupakan salah satu limbah padat organik sehingga air yang melalui media ini zat organiknya tidak berkurang melainkan bertambah, tidak seperti $\mathrm{Fe}$ yang dapat turun karena kandungan pada cangkang kerang yaitu $\mathrm{CaCO}_{3}$ dapat memisahkan ion logam dengan air. 
2) Filter Karbon Aktif (Tempurung Kelapa) Untuk Menurunkan Fe dan Zat organik Air Bersih

Hasil pemeriksaan kadar besi $(\mathrm{Fe})$ sebelum perlakuan yaitu $3,23 \mathrm{mg} / \mathrm{l}$ dengan pengulangan tiga kali untuk kontrol yaitu 2,59 setelah, dapatkan hasil yaitu $0,14 \mathrm{mg} / \mathrm{l}$ dengan efektivitas $95,66 \%$.

Hasil untuk zat organik sebelum perlakuan yaitu $51,38 \mathrm{mg} / \mathrm{l}$ dengan pengulangan tiga kali untuk kontrol yaitu 30,12 setelah, didapatkan hasil yaitu 36,33 dengan efektivitas $29,28 \%$. Menurut Hardini (2011) menyatakan bahwa karbon aktif sebagai media filter dapat menurunkan zat organik $\left(\mathrm{KMnO}_{4}\right)$ hingga $70,11 \%$.

Serta penghilang senyawa ogranik dalam air. Karbon aktif ini sangat efktif dalam menyerap zat terlarut dalam air, baik organik maupun anorganik. Oleh karena itu karbon aktif sangat efektif digunakan untuk media pengolahan air kotor menjadi air bersih.

Tempurung kelapa dapat dimanfaatkan sebagai karbon aktif dimana karbon aktif dari tempurung kelapa mempunyai nilai ekonomis yang tinggi. Tempurung kelapa merupakan bahan terbaik karena memiliki mikropori sangat banyak, kadar abu rendah, dan kelarutan dalam air sangat tinggi. Serta beberapa sifat karbon aktif dari tempurung kelapa antara lain adalah strukturnya sebagian besar mikropori, kekerasannya tinggi dan mudah diregenerasi. (Pambayun et al. 2013).

3) Metode Gabungan Media Filter Cangkang Kerang (Anadara granosa) Fe dan Zat Organik Air Bersih

Hasil pemeriksaan untuk $\mathrm{Fe}$ sebelum perlakuan yaitu $3,23 \mathrm{mg} / \mathrm{l}$ dengan pengulangan tiga kali untuk kontrol yaitu 2,59 mg/l, setelah perlakuan pada media cangkang kerang-karbon aktif didapatkan hasil rata-rata yaitu $0,23 \mathrm{mg} / \mathrm{l}$ dengan efektivitas $92,77 \%$.

Hasil untuk zat organik sebelum perlakuan yaitu $51,38 \mathrm{mg} / \mathrm{l}$ dengan pengulangan tiga kali untuk kontrol yaitu $30,12 \mathrm{mg} / \mathrm{l}$, setelah perlakuan pada media cangkang kerang-karbon aktif didapatkan hasil rata-rata yaitu $23,32 \mathrm{mg} / \mathrm{l}$ dengan efektivitas $54,59 \%$.

Efektivitas penurunan kadar besi dengan kombinasi media susunan cangkang kerang dan karbon aktif dapat dikatakan efektif meskipun pada satu media karbon aktif lebih banyak penurunannya namun kadar Fe sudah termasuk memenuhi persyaratan yaitu dibawah nilai ambang batas $1,0 \mathrm{mg} / \mathrm{l}$. Sejalan dengan penelitian Luthfiah et al. (2015) bahwa cangkang kerang kombinasi karbon aktif sebagai media filter dapat mereduksi kadar besi ( $\mathrm{Fe})$ sebesar $86.94 \%$.

Metode gabungan yang digunakan, lebih efektif dibandingkan dengan satu media dalam menurunkan zat organik karena susunan cangkang kerang yang berada dibawah kemudian karbon aktif memungkinkan air mengendap dan hasil dari endapan tersebut tidak terikut saat melalui media karbon aktif sehingga penurunan zat organik pada media kombinasi ini lebih efektif. (Joko, 2010). Berdasarkan penelitian rancangan yang telah dibuat, filtrasi menggunakan arah aliran up flow filtrasi, Sampel air didistribusikan melalui pipa dari bawah ke atas sehingga tekanan air didapatkan melalui cara gravitasi. Kelebihan pada sistem up flow filtrasi yaitu waktu tinggal penyaringan pada air lebih lama dibandingkan dengan down flow sehingga filtrasi lebih efektif dalam penurunan kadar kontaminan seperti Fe sedangkan untuk zat organik untuk penurunannya tidak sampai memenuhi persyaratan.

Media filter berpengaruh dalam proses filtrasi atau dengan kata lain media penyaring merupakan bahan yang digunakan dalam penelitian ini terdapat dua jenis yaitu cangkang kerang (Anadara granosa) dan karbon aktif. Kedua media tersebut diperlakukan sama atau homogen dengan ukuran dari media yang sama.

Zat organik yang tidak mengalami penurunan setelah melalui media cangkang kerang ini dipengaruhi oleh koloid dan waktu kontak. Koloid juga terdapat pada serbuk media cangkang kerang yang lolos melalui pemisahan ukuran media sehingga koloid yang menjadi penyebab adanya kenaikan pada zat organik dibandingan dengan media lain yaitu karbon aktif. Sedangkan untuk waktu kontaknya ini diuntungkan pada parameter besi $(\mathrm{Fe})$ sebab semakin lama waktu kontak maka semakin tinggi penurunan $\mathrm{Fe}$ nya. Pada rancangan alat filtrasi yang dibuat setiap tabung yang dilalui air tidak penuh secara bersamaan sehingga waktu kontak pada dua tabung yang ditengah lebih lama dibandingkan dengan dua tabung terluar. Dua tabung ditengah berisi masing-masing media cangkang kerang dan karbon aktif. Sehingga efektivitas penurunan media $\mathrm{Fe}$ lebih besar pada satu media dibandingkan dengan media kombinasi. 
Ukuran media filter dalam proses filtrasi mempengaruhi hasil air yang melalui proses penyaringan atau dengan kata lain biasa juga disebut ukuran efektif partikel. Untuk mengetahui perbedaan secara nyata pada media filter yang digunakan tidak boleh berbeda atau disebut dengan homogen. Maka cangkang kerang yang didapatkan tidak semata-mata langsung digunakan namun dibuat seukuran media karbon aktif dengan cara menggerus cangkang kerang sebelum digunakan namun jika terdapat serbuk cangkang saat proses penggerusan maka sisanya dipisahkan dan menggunakan cangkang yang seukuran dengan zeolit agar semua media homogen. Air yang melalui media filter.

Untuk mengetahui adanya perbedaan pada lebih dari dua intervensi dengan replikasinya. Pada hasil pemeriksaan kadar $\mathrm{Fe}$ kombinasi media susunan cangkang kerang-karbon aktif serta kontrol didapatkan nilai Sig. 0,00<0,05 untuk kadar besi $(\mathrm{Fe})$ media dibandingkan dengan kontrol yang tidak menggunakan media.

Pada parameter zat organik hasil pemeriksaan melalui proses penyaringan media filter cangkang kerang, karbon aktif, dan kombinasi media susunan cangkang kerang-karbon aktif serta kontrol didapatkan nilai Sig. 0,00, untuk kadar zat organik ada perbedaan yang signifikan pada intervensi dengan kontrol yang tidak menggunakan media.

\section{Hasil Uji Statistik}

Pada uji lebih dari dua intervensi dengan replikasinya. Pada hasil pemeriksaan kadar $\mathrm{Fe}$ dengan menggunakan media filter kombinasi media susunan cangkang kerang-karbon aktif serta kontrol didapatkan nilai Sig. 0,00 $<0,05$ ,untuk kadar besi $(\mathrm{Fe})$ media dibandingkan kontrol yang tidak menggunakan media. Namun pada hasil uji anova ini media filter digunakan jika tidak termasuk dengan kontrol.

Jika dibandingkan dengan Permenkes Khususnya pada persyaratan hygiene dari total 12 sampel untuk kadar Fe didapati 9 syarat yaitu 3 sampel setelah filtrasi melalui cangkang kerang, 3 sampel melalui zeolit, dan 3 sampel melalui kombinasi media susunan cangkang kerang-zeolit. Sedangkan untuk kadar Mn dari 12 sampel yang diperiksa tidak ada sampel yang memenuhi syarat setelah dilakukan proses filtrasi baik pada kontrol maupun pada media cangkang kerang, zeolit, dan kombinasi media susunan cangkang kerang-zeolit.
Putra et al. (2013) cangkang kerang dapat mereduksi 1,23 turun 0,08 dengan efektivitas 93,94\%. Dari penelitian Luthfiah et al. (2015) cangkang kerang kombinasi karbon aktif dengan sistem up flow filtrasi lebih efektif dalam 5,13 dengan efektifitas $86,94 \%$ dibandingkan dengan sistem down flow filtrasi yaitu efektivitasnya hanya $85,38 \%$. Adapun penelitian dengan menggunakan tiga media sekaligus oleh Pradana et al. (2018) yaitu menggunakan sistem filtrasi mereduksi 5,50 turun $0,67 \mathrm{mg} / \mathrm{l}$ dengan efektivitas $87,72 \%$.

Perbedaan zeolit Zat Organik perlakuan cangkang kerang dengan ketebalan $60 \mathrm{~cm}$, Karbon aktif dengan ketebalan $60 \mathrm{~cm}$, dan kombinasi media susunan cangkang kerangkarbon aktif masing-masing $30 \mathrm{~cm}$ pada air sumur gali di Kampung Sapiria yang menjadi sampel penelitian.

\section{KESIMPULAN}

Berdasarkan hasil penelitian yang telah dilakukan dapat disimpulkan sebagai berikut :

1. Ada penurunan kadar besi (Fe) yang signifikan dan memenuhi syarat sedangkan zat organik $\left(\mathrm{KMnO}_{4}\right)$ penurunannya tidak memenuhi syarat pada air bersih melalui pengolahan filtrasi dengan media cangkang kerang pada ketebalan $60 \mathrm{~cm}$.

2. Ada penurunan kadar besi $(\mathrm{Fe})$ dan memenuhi syarat sedangkan zat organik $\left(\mathrm{KMnO}_{4}\right)$ penurunannya tidak sesuai dengan persyaratan kualitas air bersih melalui pengolahan filtrasi dengan media karbon aktif pada ketebalan $60 \mathrm{~cm}$.

3. Ada penurunan kadar besi (Fe) dan memenuhi syarat sedangkan zat organik $\left(\mathrm{KMnO}_{4}\right)$ penurunannya tidak sesuai dengan persyaratan kualitas air bersih melalui pengolahan filtrasi dengan media cangkang kerang-karbon aktif pada ketebalan masingmasing $30 \mathrm{~cm}$.

\section{SARAN}

Berdasarkan hasil kesimpulan di atas maka penulis menyarankan sebagai berikut:

Bagi masyarakat yang ingin menggunakan pengolahan ini jika tidak bisa menggunakan kedua media sekaligus satu media saja cukup seperti cangkang kerang yang lebih efektif dibandingan media karbon aktif atau kombinasi media susunan cangkang kerang-karbon aktif yang digunakan. Selain itu jika pengolahan digunakan secara kontinyu untuk kebutuhan rumah tangga maka sebaiknya pada media filter dibersihkan pada periode waktu tertentu.

\section{DAFTAR PUSTAKA}


1. Aliya, D.R. 2010. Mengenal Teknik Penjernihan Air. Semarang: Aneka Ilmu.

2. Asmadi, Khayan, Heru Subaris Kasjono. 2011. Teknologi Pengolahan Air Minum. Yogyakarta: Gosyen Publishing.

3. Chandra, Budiman. 2006. Pengantar Kesehatan Lingkungan. Jakarta: EGC.

4. Effendi, Hefni. 2003. Telaah Kualitas Air. Yogyakarta: Kanisius.

5. Fakhrurroja, Hanif. 2010. Membuat Sumur Air Di Berbagai Lahan. Jakarta: Griya Kreasi.

6. Joko Tri. 2010. Unit Produksi Dalam Sistem Penyediaan Air Minum. Yogyakarta: Graha IImu.

7. Kusnaedi. 2010. Mengolah Air Kotor Untuk Air Minum. Jakarta: Penebar Swadaya.

8. Luthfiah, Vivi. Asmadi. dan Taufik Anwar. 2015. Perbedaan Efektivitas Sistem Up flow dan Down flow Filtrasi menggunakan Media Shell dan Karbon Aktif dalam menurunkan Level Besi (Fe) pada Air Sumur Gali Di Perumahan Star Borneo Residence 7 Pontianak Timur Sanitarian Jurnal Kesehatan. Volume 7, Nomor 2 : 158-164.

9. Mulyani, Happy. 2017. Penuntun Praktik Analisis Dan Optimasi System Penyehatan Air Minum. Yogyakarta: Pustaka Pelajar.

10. Pradana, Tedy Dian. Suharno. dan Ardan Kamarullah. 2018. Efektivitas Koagulan Bubuk Kapur dan Filtrasi dengan Metode Up Flow dan Down Flow untuk Menurunkan Fe. Jurnal Kesehatan Masyarakat Khatulistiwa JKMK. Volume 5, Nomor 1 : 32-41. (online). http://openjournal.unmuhpnk.ac.id/. Diakses 5 Desember 2018.

11. Purba, Adi Syahputra. 2018. Pembuatan dan Karakterisasi Filter Pemurnian Hidrogen Berbasis Zeolit dengan Filler Serbuk Shell Darah (Anadara granosa). Tesis. Fakultas Matematika dan Ilmu Pengetahuan Alam Universitas Sumatera Utara. Medan. (online). http://repositori.usu.ac.id/. Diakses 17 Desember 2018.

12. Putra, Yulianto Laksono. Abdul Aziz Abdullah. dan Wawan Hermawan. 2013. Pengolahan dan Penjernihan Air dengan Memanfaatkan Media Shell Bulu. Sains dan Matematika ISSN. Voume 1, Nomor 2 : 69-75. (online). https://journal.unesa.ac.id/. Diakses 5 Desember 2018.

13. Rahmawanti, Novi. dan Novrian Dony. 2016. Studi Arang Aktif Tempurung Kelapa Dalam Penjernihan Air Sumur Perumahan Baru Daerah Sungai Andai. Jurnal Keguruan dan IImu Pendidikan. 7 (2) : 87-88. (online). https:ojs.uniska-bjm.ac.id/index.php/JST/article/view/438. Diakses 27 Desember 2018.

14. Sutrisno, Totok. 2006. Teknologi Penyediaan Air Bersih. Jakarta: Rineka Cipta.

15. Wibowo, Adik. 2014. Metodologi Penelitian Praktis. Jakarta: Rajawali Pers. 